\title{
Sobre os meios e modos de fazer jornalismo na Primeira República: Lima Barreto entre a história e a ficção
}

\author{
Means and manners for making journalism during the First \\ Republic: history and fiction on Lima Barreto
}

\author{
Denilson Botelho ${ }^{1}$
}

\section{RESUMO}

Este artigo consiste na análise de um conto de Lima Barreto (1881-1922), intitulado "O jornalista", publicado na revista Souza Cruz, em 1921, a partir do qual se discute e examina os meios e modos de fazer jornalismo na Primeira República. Tomando a literatura como fonte e como um tipo de documento, investiga-se o significado dessa publicação, bem como sua relação com outros textos do autor, a fim de perceber o quanto são capazes de revelar sobre as lutas travadas no universo da imprensa. Trata-se de resultados parciais de pesquisa desenvolvida no campo da história social da cultura, tendo como referenciais teóricos as contribuições de E. P. Thompson e Raymond Williams.

Palavras-chave: Lima Barreto; Jornalismo; Imprensa; Literatura; Primeira República.

\section{ABSTRACT}

This article is the analysis of a short story written by Lima Barreto (1881-1922), entitled "The Journalist", published in Souza Cruz magazine in 1921, as it presents a discussion on the ways and means of doing journalism during the First Republic. Being the literature a source and a kind of document, the meaning of this publication is investigated, as well as its relationship to other texts of this author aiming to understand how the struggles in the world of media were revealed then. These are partial results of a research conducted in the field of social history of culture, considering the theoretical contributions of E. P. Thompson and Raymond Williams.

Keyword: Lima Barreto; Journalism; Media; Literature; First Republic.

1 Professor do Curso de História e do Programa de Pós-Graduação em História do Brasil da Universidade Federal do Piauí - UFPI. Doutor em História pela Universidade Estadual de Campinas - UNICAMP. 
Em 1921, Lima Barreto (1881-1922) publicava "O jornalista" (BARRETO, 1921a) na revista Souza Cruz, no Rio de Janeiro. Posteriormente, o conto foi novamente publicado junto com o romance Vida e morte de M. J. Gonzaga de Sá, em 1956, pela Editora Brasiliense. E mais recentemente, coube a Lilia Moritz Schwarcz reeditá-lo na coletânea Contos completos de Lima Barreto, publicado pela Companhia das Letras em 2010. Interessa-nos examinar nesse artigo algumas encruzilhadas em que, na obra desse escritor carioca, se dão o encontro entre história, imprensa e literatura. $\mathrm{O}$ conto em questão é apenas um dentre os vários textos de Lima Barreto em que a imprensa e o jornalismo estiveram no centro de sua abordagem.

É fato que tratamos aqui de um autor que é mais conhecido como romancista. Algumas de suas obras figuram hoje entre os ditos clássicos da literatura brasileira, tendo sido reeditadas por diversas vezes e inclusive adaptadas para o cinema e a teledramaturgia. Entretanto, sua trajetória foi marcada por intensa atuação na imprensa do Rio de Janeiro da Primeira República. Seus artigos e crônicas evidenciam sua presença frequente nos mais variados veículos da época, o que lhe permitiu ser também identificado como jornalista. No curto período inferior a duas décadas, foram publicados mais de 500 textos de sua lavra em jornais e revistas (BOTELHO, 2002; RESENDE; VALENÇA, 2004).

Além disso, ainda jovem, o escritor percebeu a importância da imprensa na construção de uma carreira literária e chegou mesmo a fundar a sua própria revista, Floreal ${ }^{2}$, que não foi, contudo, além da quarta edição(BOTELHO, 2005). Essa vivência como jornalista fez com que o autor construísse progressivamente uma percepção bastante crítica em relação ao papel da imprensa. E não foram poucas as vezes em que manifestou essa compreensão crítica do jornalismo através da ficção. Afinal, seu romance de estreia, Recordações do escrivão Isaías Caminha, publicado em 1909, foi um petardo contra um dos mais populares diários em circulação na Capital Federal no início do século XX (BOTELHO, 2011).

A revista Souza Cruz, na qual foi publicado o conto "O jornalista", era uma dentre as dezenas de periódicos com os quais Lima Barreto colaborou ao longo de sua vida. No ano de 1921, o autor se fez presente nas suas páginas de forma bastante regular. Em janeiro, publicou "As origens" (BARRETO, 1921b), que viria a ser o primeiro capítulo do romance Cemitério dos Vivos. Após a sua segunda internação no Hospício Nacional de Alienados, o literato recriou no plano ficcional a traumática experiência da convivência forçada com doentes psiquiátricos e outros indivíduos cujo comportamento poderia levá-los a cruzar os muros daquela instituição até mesmo pelas mãos da polícia (BARRETO, 1956a). Essa foi justamente a forma pela qual Lima Barreto foi parar no hospício: acometido de delírios em decorrência do alcoolismo, viu-se forçado à reclusão motivada por demanda da própria

${ }^{2}$ Considerando a caracterização proposta por Camargo (2008, p. 255), esta seria uma típica revista literária, não por tratar de assuntos literários ou que publica matéria literária (embora Floreal tenha essa característica também), mas por reunir os seguintes atributos: "tiragens reduzidas, circulação em âmbitos restritos, pouco ou nenhum espaço publicitário, ausência de financiamentos oficiais e institucionais, existência efêmera". 
família - embora tenha cuidado do pai, este sim um doente psiquiátrico, dentro da própria casa, durante cerca de 20 anos, sem jamais submetê-lo a uma internação. O romance permaneceu inacabado, sendo publicado após a morte do escritor ${ }^{3}$.

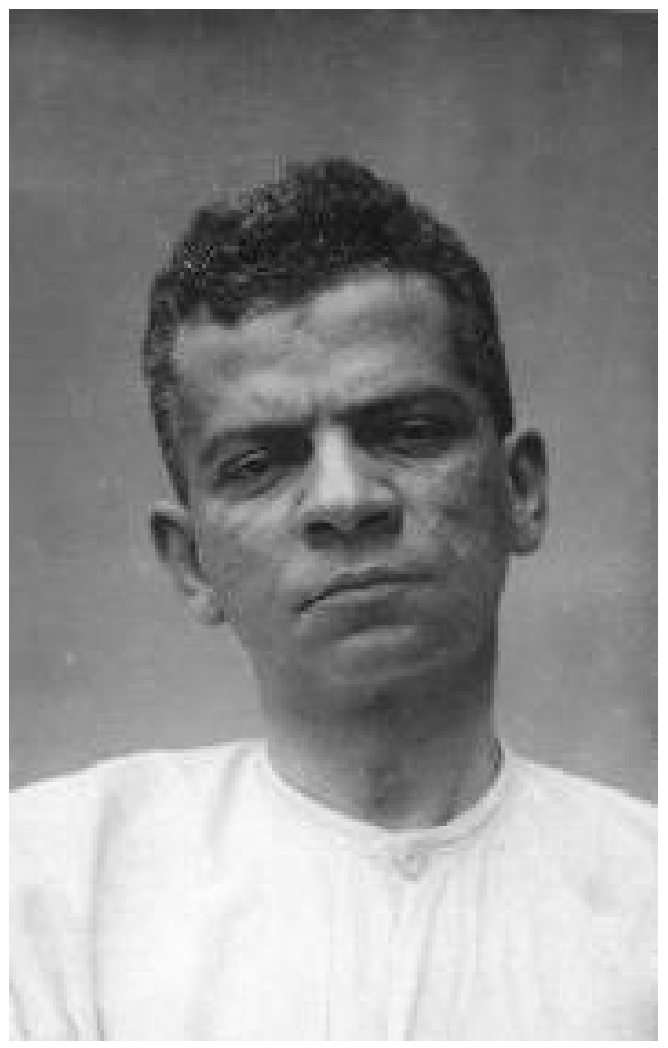

Fotografia de Lima Barreto, aos 38 anos de idade, que consta do prontuário de sua última internação no hospício. A imagem foi localizada nos arquivos do Instituto de Psiquiatria da Universidade Federal do Rio de Janeiro. Vale ressaltar que nesta mesma página do prontuário, consta que sua profissão era a de jornalista. (RESENDE; VALENÇA, 2004, p. 41).

Nos números 58 e 59, de outubro e novembro do mesmo 1921, a revista publicava o texto de uma rara conferência que o escritor redigiu (BARRETO, 1921c), mas jamais pronunciou. Segundo o biógrafo Francisco de Assis Barbosa, a história dessa conferência que não foi, começou na única homenagem ${ }^{4}$ que o literato recebeu em vida, em 1920: "um almoço,

\footnotetext{
3 Nesta edição publicou-se também um diário elaborado pelo escritor durante a sua segunda internação, entre 25 de dezembro de 1919 e 2 de fevereiro de 1920. Também foram reproduzidos no mesmo livro documentos relativos às duas internações de Lima Barreto no Hospício. Em ambas consta o mesmo diagnóstico: alcoolismo. Da anamnese feita na segunda internação, quando o escritor tinha 38 anos de idade, consta o seguinte: "É um indivíduo precocemente envelhecido, de olhar amortecido, fácies de bebedor, regularmente nutrido. Perfeitamente orientado no tempo, lugar e meio, confessa desde logo fazer uso, em larga escala, de parati; compreende ser um vício muito prejudicial, porém, apesar de enormes esforços, não consegue deixar a bebida" (BARRETO, 1956a, p. 265).

${ }^{4}$ A homenagem foi objeto da crônica "O meu almoço", publicada n'A Notícia, em 3 de junho de 1920 (BARRETO, 1956b, p. 280-286).
} 
promovido por Francisco Schettino ${ }^{5}$, no Hotel Novo Democrata. Uma vastíssima feijoada, regada com muita cachaça, onde todos falaram, menos o homenageado, que permaneceu 'mudo que nem um peixe' durante o bródio" (BARBOSA, 1988, p. 262-263). Dentre os vários companheiros de jornalismo e de bar, estava presente o médico e escritor Ranulfo Prata ${ }^{6}$.

O encontro com Lima Barreto produziria em Ranulfo Prata, que viera de São Paulo, cheio de admiração para conhecê-lo, uma tal impressão de débâcle que o jovem médico e escritor tomaria a si a empreitada de tentar a recuperação do romancista. A primeira providência seria retirá-lo do Rio. E Prata convidou-o a passar uma temporada em Mirassol, pequena cidade do interior paulista, onde clinicava, acreditando que assim pudesse 'salvar' o companheiro de letras, vencido pela desilusão e pelo tédio de viver. (BARBOSA, 1988, p. 263)

Ainda segundo o biógrafo, a impressão inicial que Prata teve do homenageado explicase, em parte, pelo modo como este habitualmente se apresentava: "Andrajoso, não dispensava a palheta amassada e encardida, assentada na carapinha que grisalhava", perambulando "pelas ruas do Rio de Janeiro, como se fosse um pobre-diabo desconhecido, quase um mendigo, a quem os donos da vida apontavam, ora como um bêbado qualquer, ora como um sujeito amalucado" (BARBOSA, 1988, p. 262-263).

\footnotetext{
${ }^{5}$ Francisco Schettino nasceu em 1896 e faleceu em 1944, aos 48 anos de idade. Embora fosse 15 anos mais jovem que Lima Barreto, foi um amigo fiel e dedicado ao escritor. Exerceu atividades de editor e livreiro. A Livraria Schettino, na rua Sachet, era ponto de encontro de literatos da época. Mas como a literatura o interessava mais como arte do que como negócio, a livraria acabou fechando. Trocou diversas cartas com Lima Barreto nos seus últimos anos de vida, entre 1918 e 1922. Em 1920, numa dessas correspondências, examinaram a possibilidade de irem juntos para o Piauí, a convite do amigo em comum, João Luis Ferreira, companheiro da juventude que tornara-se governador do Estado. Em carta, Schettino chega a perguntar a Lima: "Vamos para lá?" Não foram. Como registro da amizade, ficou a dedicatória de Triste fim de Policarpo Quaresma a João Luís Ferreira. (BARBOSA, 1988, p. 244-245; BARRETO, 1956d, p. 85-134).

${ }^{6}$ Ranulfo Hora Prata nasceu em Lagarto, Sergipe, em 4 de maio de 1896. Teve passagens por Simão Dias, Estância e Bahia, quando procurou consolidar a sua formação educacional. No Rio de Janeiro, doutorou-se em 1919 pela Faculdade Rio de Janeiro. Viveu a maior parte de sua vida em São Paulo, mais precisamente nas cidades de Mirassol e Santos, onde exerceu a medicina. Faleceu em São Paulo, no dia 24 de dezembro de 1942 (SCHWARCZ, 2010, p. 697; CARVALHO NETO, 1974).
} 


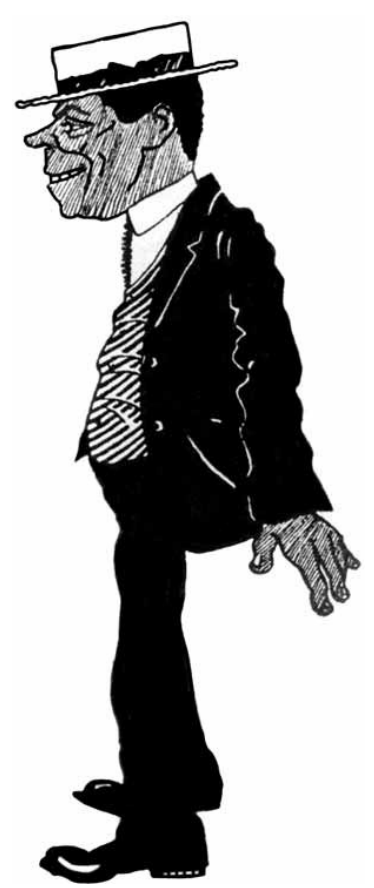

A impressão inicial que Ranulfo Prata teve de Lima Barreto faz lembrar, em certa medida, com essa caricatura de Hugo Pires, publicada na revista A Cigarra, de São Paulo, em 1919 (BARRETO, 1956c).

Lima Barreto aceitou o convite do novo amigo e embarcou num trem da Central do Brasil rumo a Mirassol. "De passagem por São Paulo, Lima Barreto visitaria os companheiros do anarquismo, que apenas conhecia de nome, como Edgar Leuenroth e João da Costa Pimenta, na redação da Vanguarda, e procuraria, no escritório da sua casa editora, a Monteiro Lobato" (BARBOSA, 1988, p. 264). Na cidade destino, sob os cuidados de Ranulfo Prata, submeteu-se a uma nova dieta alimentar, adquiriu uma fisionomia mais saudável e, por algum tempo, abandonou o álcool. Até que surgiu o convite para a tal conferência, resultado do entusiasmo de amigos de Prata com a presença do escritor carioca naquelas terras. A conferência aconteceria em Rio Preto, sede da comarca, a poucos quilômetros de Mirassol.

O fato de jamais ter pronunciado uma conferência, associado a uma notória timidez, desencadeou no escritor um nervosismo e ansiedade que acabaram impedindo-o de protagonizar tamanha exposição pública. Na data combinada, Lima Barreto simplesmente desapareceu e, por mais que o procurassem, não foi encontrado a tempo. Foi Ranulfo Prata que "acabou encontrando o amigo, estirado numa sarjeta. Bêbado" (BARBOSA, 1988, p. 265).

Deste episódio, restou, contudo, um texto revelador do sentido que o escritor atribuía a sua arte. Fica patenteado o caráter militante e engajado que Lima Barreto atribui à literatura: "o fenômeno artístico é um fenômeno social e o da Arte é social para não dizer sociológico" 
(BARRETO, 1956e, p. 56). Conforme $\operatorname{argumentamos}^{7}$ em outro artigo (BOTELHO; AZEVEDO NETO, 2012), para o escritor carioca, uma literatura esteticamente bela seria aquela que:

[...] sem desprezar os atributos externos de perfeição de forma, de estilo, de correção gramatical, de ritmo vocabular, de jogo e equilíbrio das partes em vista de um fim, de obter unidade na variedade; uma tal importância [...], deve residir na exteriorização de um certo e determinado pensamento de interesse humano, que fale do problema angustioso do nosso destino em face do Infinito e do Mistério que nos cerca, e aluda às questões de nossa conduta de vida. (BARRETO, 1956e, p. 58-59)

E foi justamente a Ranulfo Prata que Lima Barreto dedicou o conto "O jornalista", por ocasião de sua publicação na Souza Cruz. O gesto sugere gratidão pelo amigo que mostrarase sensível às dificuldades enfrentadas pelo escritor, tentando lhe proporcionar uma oportunidade de curar-se do vício da embriaguez, ao mesmo tempo em que apostava no seu talento literário. De qualquer modo, a dedicatória a Ranulfo Prata funciona como um elo que estabelece uma importante relação entre os dois textos: a conferência jamais pronunciada evidencia a concepção de literatura como arte da intervenção sobre a realidade, que o autor põe em prática no conto, no qual formula uma crítica e uma denúncia sobre os meios e modos de fazer jornalismo na Primeira República.

Ainda acerca dessa relação, vale ressaltar que ela teve início a partir da remessa que Ranulfo fez a Lima do romance com o qual estreou na literatura. Como frequentemente exerceu a crítica literária, Lima Barreto publicaria ainda em setembro 1918, no A.B.C., uma apreciação sobre $O$ Triunfo, de Ranulfo Prata (BARRETO, 1956e, p. 126-129). O estreante recebeu elogios do crítico: "É um romance, antes, uma novela em que o autor revela grandes qualidades para o gênero. Já possui a sobriedade de dizer, a naturalidade do diálogo e não limalha a frase estafadamente". Mas o crítico não deixou de lhe apontar aspectos estéticos negativos, como a teimosia em atribuir uma pretensa beleza "às moças dessas cidadezinhas" do interior, a tal ponto que esta seria capaz de lhes transformar a vida: "A Angelina do Senhor Prata é linda, é bela e, de meninota da roça, passa logo a coquette do Rio, cheia de amantes. [...] Duvido que seja assim". Por isso,

[...] aconselho abandonar toda a preocupação de elegâncias para só atender o que é propriamente de sua arte: a alma humana e os costumes. [...] Se ainda lhe falta, talvez, uma profunda e sagaz visão da vida, sobram-lhe outras qualidades de escritor que suprem aquela falta (BARRETO, 1956e, p. 126-129).

\footnotetext{
${ }^{7}$ Robert John Oakley (2011) compartilha do mesmo argumento.
} 
Os comentários que beiravam a aspereza em 1918, parecem não ter motivado qualquer ressentimento a ponto de abalar os generosos propósitos do amigo que levaria Lima Barreto em 1920 para Mirassol, a fim de tentar curar o seu vício devastador.

A grande maioria dos periódicos nos quais Lima Barreto publicava seus textos era de pequena expressão, resultado de iniciativas coletivas marcadas pela carência de recursos, com distribuição precária, além de baixas tiragens. Ou seja, não faziam parte do que se poderia denominar como a grande imprensa da época. Contudo, havia exceções como as revistas Careta e Souza Cruz, que nos interessa aqui particularmente, por ter sido o meio através do qual "O jornalista” veio a público.

Criada em 1916, a Souza Cruz, foi uma publicação mensal que circulou por 18 anos ininterruptos e marcou o jornalismo empresarial brasileiro, financiada pela indústria do fumo que deu título a revista. Dirigida por Herbert Moses $^{8}$, a revista contou com a colaboração dos escritores Olavo Bilac, Augusto dos Anjos, Graça Aranha, Lima Barreto, Manuel Bandeira, Catulo da Paixão Cearense e Humberto de Campos, entre outros, e teve como ilustradores, Portinari e Di Cavalcanti. Moses foi um homem de imprensa bem articulado que, além de redator da Souza Cruz, também acompanhou Irineu Marinho na fundação do jornal $O \mathrm{Globo}^{9}$, em 1925, e tornou-se presidente da Associação Brasileira de Imprensa numa concorrida eleição disputada com Ernesto Pereira Carneiro, do Jornal do Brasil, e Oscar Costa, do Jornal do Commercio.

É possível conjecturar que a presença de Lima Barreto nas páginas da Souza Cruz se deva a uma relação de longa data com Herbert Moses. Na alvorada do século XX, ambos estiveram envolvidos em atividades da Federação de Estudantes fundada no Rio de Janeiro, em 1901. Essa entidade foi criada por iniciativa de Everardo Backheuser, que

[...] levanta essa bandeira, na Escola Politécnica, convocando colegas influentes, Heitor Lira entre eles, e os que formavam o seu grupo de antigos alunos do Ginásio Nacional, alguns dos quais, como o próprio

\footnotetext{
${ }^{8}$ Herbert Moses nasceu no Rio de Janeiro, em 27 de julho de 1884, filho do austríaco Inácio Moses e da norte-americana Ida Moses. Estudou no Colégio Americano Fluminense e no Externato Aquino, ingressando em 1900 na Faculdade Livre de Ciências Jurídicas e Sociais do Rio de Janeiro, bacharelando-se em dezembro de 1905. Ainda em 1898, quando cursava o ensino secundário, fundou com Pedro Berquó o jornal $O$ Estudante. Exerceu a advocacia depois de formado e fundou, junto com Irineu Marinho o jornal A Noite, em 1911, e $O$ Globo, em 1925. Foi diretor-tesoureiro d'O Globo desde a fundação até pouco antes de morrer. Foi presidente da Associação Brasileira de Imprensa - ABI durante 33 anos, reelegendo-se sucessivamente. Destacou-se na defesa da liberdade de imprensa e contra as violências praticadas contra jornais e jornalistas. Faleceu no Rio de Janeiro em 11 de maio de 1972 (FERREIRA, 2001, p. 3922-3923; CARVALHO, 2012).

9 Moses não apenas participou da fundação deste jornal, tendo mais tarde se tornado vice-presidente da Empresa Jornalística Brasileira S.A., presidida por Roberto Marinho ao tempo em que mantinha $O$ Globo, na década de 1950. A referida empresa obteve significativos empréstimos junto ao Banco do Brasil durante o segundo governo de Getúlio Vargas, ao mesmo tempo em que participava ativamente da campanha contra os empréstimos feitos pelo mesmo banco à Última Hora, dirigido por Samuel Wainer. A contradição oportunista do jornal não escapa a Sodré (1966, p. 460-462).
} 
Backheuser, eram socialistas ou se diziam tais, seguidores e admiradores do professor de latim Vicente de Sousa, fundador da Federação Operária. (SODRÉ, 1966, p. 351).

Ainda segundo Sodré, "ingressaram logo na organização estudantil Levi Carneiro, Herbert Moses, Eduardo Rabelo, Oscar Rodrigues Alves, Aloísio de Castro, Heitor Lira, sendo este eleito presidente" (SODRÉ, 1966, p. 351). O manifesto inicial da Federação de Estudantes duvidava da existência de uma opinião nacional no Brasil e defendia a instrução para os operários, como instrumento necessário no enfrentamento do nosso "problema social" (SODRÉ, 1966, p. 351). Certamente Moses e Lima Barreto se conheceram devido à participação deste no jornal $A$ Lanterna, mantido pela entidade estudantil e fundado por Júlio Pompeu de Castro. Aluno da Escola Politécnica nessa época, aceitou convite de Bastos Tigre e passou a escrever nas páginas desse periódico, que abandonou pouco tempo depois por discordar de uma representação dirigida pela Federação ao Congresso Nacional, em defesa do serviço militar obrigatório (SODRÉ, 1966, p. 351).

Em 1921, quando já havia sido aposentado do serviço público na Secretaria da Guerra e tentava sobreviver daquilo que escrevia, Lima Barreto deve ter visto na oportunidade de publicar na Souza Cruz, um meio de garantir recursos para a sua sobrevivência, publicando numa revista mantida pela indústria do tabaco e dirigida por um colega de longa data.

Vale ressaltar que a abordagem do conto "O jornalista", aqui proposta, situa-se no campo oposto àquele denominado por alguns pesquisadores dessa virada para o século XXI como "pós-moderno". Interessados por cultura, identidade e discurso, argumentam que a linguagem é tudo o que podemos conhecer sobre o passado e o mundo. A linguagem tornouse, para muitos, o lugar de acontecimento da história, já que não teríamos como conhecer o mundo, nem ter acesso a qualquer realidade. A sociedade aproxima-se assim do discurso sobre ela produzido, quando não é lançada numa vala comum que iguala discurso e realidade (WOOD, 1999, p. 11).

Rejeitando por completo essa curiosa vertente de estudos, que transformou a cultura em diversidade e pluralidade, deixando ao pesquisador a tarefa indigente de perceber apenas diferenças e identidades, e fazendo-nos submergir num perigoso relativismo que ainda por cima destitui o universo da cultura da sua materialidade e dos seus aspectos inegavelmente concretos, optamos por uma abordagem da cultura apoiada nas contribuições de Raymond Williams e Edward Palmer Thompson.

Como não temos dúvidas sobre a existência do passado e sabemos que dele não restaram apenas discursos que podemos interpretar ao nosso bel prazer, impõe-se a compreensão das experiências de luta travadas por Lima Barreto. Só assim é possível identificar uma vertente contra-hegemônica no interior da imprensa carioca durante a Primeira República, a despeito do caráter conservador do jornalismo brasileiro naquele 
período. Trata-se de uma tendência que tem entre seus expoentes "os escritores, artistas, jornalistas que, colocando-se contra a corrente dominante, propuseram uma imagem alternativa de Nação" (COUTINHO, 2008, p. 66) ou que sonharam com uma sociedade brasileira que acabou não se concretizando nas primeiras décadas republicanas (BOTELHO, 2002), num movimento que Eduardo Granja Coutinho define como processos contrahegemônicos na imprensa daquele período.

\begin{abstract}
Parafraseando Marx, pode-se dizer que toda hegemonia traz em si o germe da contra-hegemonia. Há na verdade uma unidade dialética entre ambas, uma se definindo pela outra. Isto porque a hegemonia não é algo estático, uma ideologia pronta e acabada. Uma hegemonia viva é um processo. Um processo de luta pela cultura. "Deve ser continuamente renovada, recriada, defendida e modificada e é, continuamente, resistida, limitada, alterada, desafiada por pressões que não são suas", observa Raymond Williams (COUTINHO, 2008, p. 77).
\end{abstract}

Superado o paradigma da determinação econômica, Raymond Williams concebe a cultura como elemento constitutivo do processo social, como um modo de produção de significados e valores da sociedade (CEVASCO, 2003, p. 112-113). As artes e as práticas culturais - como a literatura - podem até refletir a sociedade, mas também produzem significados que transformam a sociedade, e que agem, portanto, sobre esta.

Ao analisar a obra e a trajetória desse escritor carioca, Nicolau Sevcenko (2003) percebeu claramente de que forma ele fez das letras um instrumento de intervenção na realidade concreta de um modo geral, e particularmente no jornalismo. Esta percepção pode ser sintetizada no seguinte trecho, em que fica evidenciado o desejo do literato de fazer um jornalismo diferenciado, contra-hegemônico e, quiçá, o que poderíamos denominar como jornalismo literário:

Ao problema do amesquinhamento da linguagem e da literatura, ele tentaria responder ainda com uma reinfusão de atualidade que as tonificasse, recuperando-lhes a antiga força e eficácia. Iria buscar esse tom de atualidade no fenômeno cultural que dividia com a ciência a hegemonia das convicções do período - o jornalismo. O autor, eternamente às turras com o jornalismo suspeito do país, apenas o admitia tacitamente. No entanto, o efeito dessa opção sobre a sua arte era decisivo e mais do que evidente. Sua estética, por meio do viés do jornalismo, se distinguiria principalmente pela simplicidade, pelo despojamento, contenção e espírito de síntese, aplicados à linguagem narrativa; enquanto que o tratamento temático se voltaria para o cotidiano, os tipos comuns, as cenas de rua, os fatos banais e a linguagem usual. (SEVCENKO, 2003, p. 198). 
Um texto ficcional, como o conto citado de Lima Barreto, é aqui concebido desta forma. Não apenas como reflexo, mas principalmente como intervenção numa determinada realidade. Cabe-nos investigar a natureza dessa intervenção que tem em Salomão Nabor de Azevedo seu personagem principal nesse texto de ficção. Vivendo na cidade de Sant'Ana dos Pescadores, situada entre o mar e a montanha, próximo do Rio de Janeiro, tornou-se um dos seus mais célebres habitantes. Naquela cidadezinha, "as pessoas importantes eram o juiz de direito, o promotor, o escrivão, os professores públicos, o presidente da Câmara e o respectivo secretário" (BARRETO, 2010, p. 528). Salomão Nabor era o secretário do presidente da Câmara e a figura mais importante da localidade "porque, além disso, se fizera o jornalista popular do lugar" (BARRETO, 2010, p. 528).

Viveu no final do século XIX, período em que o país transitava da monarquia à república e abolia a escravidão. Como "descendente dos antigos Nabores de Azevedo de 'serra acima' e dos Breves, ricos fazendeiros" (BARRETO, 2010, p. 528), herdou uma fazenda do pai, que vendeu e lhe permitiu comprar uma casa em Sant'Ana, onde casou-se. O modo de vida do protagonista é descrito da seguinte forma por Lima Barreto:

Vivia a fazer política e a ler os jornais da corte, que assinava. Deixou os romances e apaixonou-se por José do Patrocínio, Ferreira de Menezes, Joaquim Serra e outros jornalistas dos tempos calorosos da Abolição. Era abolicionista, porque [...] os seus escravos, ele os tinha vendido com a fazenda que herdara; e os poucos que tinha em casa, dizia que não os libertava, por serem da mulher.

O seu abolicionismo, com a lei de 13 de Maio, veio dar, naturalmente, algum prejuízo à esposa [...] (BARRETO, 2010, p. 528-529).

A convicção abolicionista de Salomão de Azevedo dá bem a medida do seu oportunismo, cujo tom farsesco o autor desnuda e denuncia. Após a instauração da república e a abolição, foi por várias vezes subdelegado e vereador, até que o promotor Fagundes, conhecedor de sua mania por jornais, lhe sugeriu fundar um jornal na cidade. Nabor reagiu com entusiasmo, refletindo a postura irônica e crítica do autor em relação ao progresso e a própria imprensa:

- Boa ideia, 'seu' Fagundes! A 'estrela do Abraão' (assim era chamada Sant'Ana) não ter um jornal! Uma cidade como esta, pátria de tantas glórias, de tão honrosas tradições, sem essa alavanca do progresso que é a imprensa, esse fanal que guia a humanidade - não é possível! (BARRETO, 2010, p. 529). 
Como o promotor não tinha o capital necessário, "Nabor entrou com o cobre; e Fagundes ficou com a direção intelectual do jornal. Fagundes era mais burro e, talvez, mais ignorante do que Nabor" (BARRETO, 2010, p. 529). Foi assim que surgiu O Arauto, um jornal semanal, cujo conteúdo é descrito do seguinte modo: "saía sempre com um artiguete laudatório do diretor, à guisa de artigo de fundo, umas composições líricas, em prosa, de Nabor, aniversários, uns mofinos anúncios e os editais da Câmara Municipal" (BARRETO, 2010, p. 529). Além disso, às vezes, Nabor "cortava alguma coisa de valia dos jornais do Rio e o jornaleco ficava literalmente esmagado ou inundado" (BARRETO, 2010, p. 529).

Contudo, a rivalidade entre o proprietário e o diretor do jornal era latente. No conto, essa rivalidade parece referir-se a algo mais do que uma disputa pessoal acerca do comando d'O Arauto. O que está em jogo são os embates entre diferentes modos de fazer jornalismo num período em que a imprensa, o Rio de Janeiro e o país atravessam profundas transformações. Trata-se do embate entre o jornalismo moderno e o tradicional, que são devidamente caracterizados no texto literário.

Nabor é apresentado como o jornalista moderno e dotado de qualidade profissional. Isso significa que está permanentemente empenhado em fazer d'O Arauto "um jornal de escândalo, de altas reportagens sensacionais, de enquete com notáveis personagens da localidade, enfim, um jornal moderno" (BARRETO, 2010, p. 529). Por outro lado, o promotor Fagundes queria fazer "um quotidiano doutrinário, sem demasias, sem escândalos - um Jornal do Commercio de Sant'Ana dos Pescadores, a 'Princesa' do 'O Seio de Abraão', a mais formosa enseada do estado do Rio" (BARRETO, 2010, p. 529-530).

O fato é que Nabor entendia o jornal como uma fábrica de notícias e aplicava a sua inventiva criatividade na transformação de episódios pouco ou nada relevantes em informação merecedora de destaque nas páginas do seu semanário. Certa vez, o naufrágio banal de uma canoa de pescaria numa praia de Sant'Ana mereceu três longas colunas e motivou reclamação de Fagundes: “- Você está gastando papel à toa!" Afinal, diria ainda, "não morrera um só tripulante" (BARRETO, 2010, p. 530). Em resposta, o argumento de Nabor é bastante eloquente: “- É assim que se procede no Rio com os naufrágios sensacionais" (BARRETO, 2010, p. 530).

O modo de fazer jornalismo da capital é enaltecido e aparece como modelo a ser copiado, ainda que se trate de fazer de uma canoa afundada um naufrágio sensacional, ou seja, de inventar uma notícia que não existe para fisgar o leitor. De algum modo, o que está em curso aqui é a construção de um fazer jornalístico que vai se tornando hegemônico tanto no texto ficcional de Lima Barreto quanto na história da imprensa brasileira no período da Primeira República.

Não é por outro motivo que a rivalidade entre os realizadores d'O Arauto chega ao seu ápice e, diante de uma nova reclamação de Fagundes, Nabor providenciou um desfecho para 
aquela "guerra surda": "- Os tipos são meus; a máquina é minha; portanto, o jornal é meu" (BARRETO, 2010, p. 530), e concretizou-se a dissidência, ficando Nabor o único dono do jornal.

\begin{abstract}
Dono do grande órgão, tratou de modificar-lhe o feitio carrança que lhe imprimira o pastrana do Fagundes. Fez inquéritos com o sacristão da irmandade; atacou os abusos das autoridades da Capitania do Porto; propôs, a exemplo de Paris etc., o estabelecimento do exame das amas de leite etc. etc. Mas nada disso deu retumbância a seu jornal. Certo dia, lendo a notícia de um grande incêndio no Rio, acudiu-lhe a idéia de que se houvesse um em Sant"Ana, podia publicar uma notícia de 'escacha', no seu jornal, e esmagar o rival - O Baluarte - que era dirigido pelo promotor Fagundes, o antigo companheiro e inimigo. (BARRETO, 2010, p. 530-531).
\end{abstract}

Este trecho quase derradeiro do conto remete a outro personagem mais conhecido de Lima Barreto, o escrivão Isaías Caminha, no momento em que testemunha com certa perplexidade o modo como se constrói a notícia no fictício jornal notoriamente inspirado no Correio da Manhã, dirigindo por Edmundo Bittencourt. No capítulo VIII, Isaías Caminha vai à redação d'O Globo em busca dos préstimos de Gregoróvitch. Não o encontrando no local, põe-se a aguardar por ele. A espera lhe dá a oportunidade de observar os bastidores da imprensa, que descreve com riqueza de detalhes. Presenciou, por exemplo, a chegada à redação de um "grande romancista de luxuoso vocabulário, o fecundo conteur, o enfático escritor a quem eu me tinha habituado a admirar desde os quatorze anos" (BARRETO, 2001a, p. 191), conhecido como Veiga Filho. O motivo da ida do famoso romancista à redação era para checar se o jornal noticiaria uma conferência que proferiu. Em meio à discussão sobre quem redigiria o texto dessa notícia, Caminha presenciou o secretário da redação sugerir que o próprio Veiga Filho fizesse o texto. E perplexo, viu aquele "homem extraordinário que a gente tinha que ler com um dicionário na mão" (BARRETO, 2001a, p. 191) acatar a sugestão.

Eu demorei-me ainda muito e pude ouvi-lo ler a notícia. Começou dizendo que era impossível resumir uma conferência de um artista como Veiga Filho. Para ele, as palavras eram a própria substância de sua arte.

[...] Veiga Filho acabou de ler a notícia no meio da sala, cercada de redatores e repórteres. Enquanto ele lia cheio de paixão, esquecido de que fora ele mesmo o autor de tão lindos elogios, fiquei também esquecido e convencido do seu malabarismo vocabular, do sopro heróico de sua palavra, da sua erudição e do seu saber..

Cessando, lembrei-me que amanhã tudo aquilo ia ser lido pelo Brasil boquiaberto de admiração, como um elogio valioso, isto é, nascido de entusiasmo sem dependência com a pessoa, como coisa feita por um admirador mal conhecido! A Glória! A Glória! E de repente, repontaramme dúvidas: e todos os que passaram não teriam sido assim? 
Naquela hora, presenciando tudo aquilo eu senti que tinha travado conhecimento com um engenhoso aparelho de aparições e eclipses, espécie complicada de tablado de mágica e espelho prestidigitador, provocando ilusões, fantasmagorias, ressurgimentos, glorificações e apoteoses com pedacinhos de chumbo, uma máquina Marinoni e a estupidez das multidões. (BARRETO, 2001a, p. 192-193).

Esta obra enseja também a denúncia dos "farejadores de escândalos", a ênfase nos assuntos grotescos ou pitorescos, característica daquele novo fazer jornalístico do início do século XX. Nesse sentido, cabe examinar uma sugestiva comparação proposta pelo autor, entre "o pirata antigo e o jornalista moderno":

\begin{abstract}
A Imprensa! Que quadrilha! Fiquem vocês sabendo que, se o BarbaRoxa ressuscitasse, agora com os nossos velozes cruzados e formidáveis couraçados, só poderia dar plena expansão à sua atividade se se fizesse jornalista. Nada há tão parecido como o pirata antigo e o jornalista moderno: a mesma fraqueza de meios, servida por uma coragem de salteador; conhecimentos elementares do instrumento de que lançam mão e um olhar seguro, uma adivinhação, um faro para achar a presa e uma insensibilidade, uma ausência de senso moral a toda a prova... e assim dominam tudo, aterram, fazem que todas as manifestações de nossa vida coletiva dependam do assentimento e da sua aprovação... Todos nós temos que nos submeter a eles, adulá-los, chamá-los de gênios, embora, intimamente os sintamos ignorantes, parvos, imorais e bestas... (BARRETO, 2001a, p.177.)
\end{abstract}

À despeito de uma excessiva valorização do papel da imprensa que se observa no trecho acima - e que é preciso relativizar e examinar de forma cuidadosa -, entendo que a obra de Lima Barreto oferece diversas passagens que fomentam debates sobre a função social da imprensa e do jornalismo na Primeira República.

E para que não se pense que apenas Recordações do escrivão Isaías Caminha aborda o tema em questão, convém referirmo-nos também a Numa e a Ninfa. Publicado entre 15 de março e 26 de julho de 1915, no formato folhetim que ocupava a parte inferior da quarta página do jornal $A$ Noite, refletia "a contundência de Lima Barreto contra a corrupção em todos os níveis e o jornalismo como fachada de negócios escusos" (CARVALHO, 2012, p. 126). Este é um romance menos conhecido - depois de publicado em livro -, no qual Lima Barreto descreve, a certa altura, uma visita do dono do jornal Diário Mercantil à residência do deputado Numa Pompílio de Castro. Antes, contudo, vale atentar para o título sugestivo desse jornal, pois o Diário Mercantil é usado para fazer negócios, um diário mercantil mesmo, usado para mercadejar. O dono do jornal, Fuas Bandeira, era português de nascimento e é descrito do seguinte modo no romance: "desde muito se achava no Brasil, metido em coisas de jornal. Homem inteligente, não era nem ignorante nem instruído. 
Tinha a instrução e a inteligência de homem de comércio e pusera na sua atividade jornalística, o seu espírito e educação comerciais" (BARRETO, 2001b, p. 428).

Logo em seguida, o autor explica como Fuas Bandeira se fez dono do referido jornal:

Fuas foi durante muito tempo um fura-vidas sem felicidade. [...] Um belo dia, a magnanimidade de um patrício fê-lo empregado da gerência do Diário, mais tarde gerente e, quando o proprietário foi à Europa, deu-lhe procuração em causa própria para tratar dos negócios da empresa; e Fuas se serviu do instrumento para se apossar dos cabedais do protetor, não só dos que giravam na empresa, como dos particulares que ele soube, com a mais requintada má-fé e com a ousadia de ladrão profissional, arrancar à inexperiência de uma velha parenta do seu benfeitor e amigo, sob cuja guarda estavam" (BARRETO, 2001b, p. 429).

De posse do jornal, Fuas passou a utilizá-lo para obter recursos públicos do Tesouro.

Daí em diante, a sua fortuna estava feita [...]. Nunca mais lhe faltou dinheiro, e muito sempre obteve, por este ou aquele meio escuso e cínico. Apesar disto, a sua folha sempre andava em concordatas, devendo ao pessoal; o que, a todos, causava admiração, pois Fuas, ao que diziam, tinha até aí, recebido de vários governos do Brasil cerca de três mil contos. Não é de espantar, quando se considera que só da vez em que se viu atrapalhado com o antigo proprietário do Diário, ele conseguiu em dias, graças às ordens do presidente da República, obter quase mil e quinhentos contos. Todo esse dinheiro que ele 'cavava', empregava-o em aparentar largueza, peitar disfarçadamente os influentes e mais depressa perdia cinquenta contos no jogo do que pagava, dos três em atraso, um mês à reportagem. Era preciso não perder a linha...

Encarava todo o debate jornalístico como objeto de comércio ou indústria e estendera esse critério aos casos políticos, às pretensões de qualquer natureza. Dizia-o mesmo francamente e francamente agia, embora, quando acusado publicamente, se defendesse indignado.

Fazia uma vida brilhante: gastava, jogava, presenteava, mas a sua generosidade era sempre interesseira. Ele a tinha com os poderosos da indústria, do comércio, da política e dos negócios; e, nos apertos, não sacrificava um ceitil de suas despesas, para atender ao pagamento dos salários dos seus próprios criados.

[...]

Seguia-lhe a política, advogava este ou aquele partido, gabava tal ou qual personagem sem remuneração alguma e até com prejuízo. Fazia, porém, entre nós sistematicamente a indústria do jornal e não havia empreendimento ou obra, por mais útil que fosse, representando emprego de capitais avultados e lucro para os empreiteiros, de que não procurasse tirar o seu quinhão. 
Não acumulava dinheiro, talvez não sentisse vontade de voltar à terra de origem e tinha o Brasil na conta de mina inesgotável que, para darlhe lucro, precisava estar-lhe à testa.

Conhecia todos os poderosos, os que se faziam poderosos, os que se iam fazendo e prometiam sê-lo, e a nenhum se acanhava de pedir isto ou aquilo. À proporção que subiam, subiam os seus pedidos; e, dessa forma, quando no fastígio, podia pedir-lhes o que quisesse (BARRETO, 2001b, p. 429).

Por esta razão é que Fuas Bandeira foi bater à porta da casa do Deputado Numa Pompílio de Castro, que se notabilizara recentemente ao proferir discurso na Câmara em defesa da venda - ou privatização - da Estrada de Ferro de Mato Grosso. Bandeira vislumbrava ali mais uma oportunidade de praticar o "jornalismo de negócios" ou a “indústria do jornal”, engrenagem principal do seu Diário Mercantil.

Portanto, esse é mais um trecho de romance bastante sugestivo do que pensa Lima Barreto sobre os homens de imprensa do seu tempo. O jornalismo apresentava-se como atividade venal e o dono do jornal como um gangster, ladrão inequívoco. Esta era a imprensa sobre a qual o romancista voltava sua artilharia crítica: uma imprensa sem o menor compromisso com a função pública de informar e servir a sociedade, ou mesmo com a isenção e a imparcialidade.

Ao mesmo tempo em que formula a crítica ao jornalismo e à imprensa do período, Lima Barreto também tenta fazer do jornalismo o que ele idealizava. Foi por esta razão que, a certa altura de sua vida, criou e dirigiu sua própria revista: a Floreal. O editorial da publicação apontava de imediato a direção a ser seguida pela revista: "É uma revista individualista, em que cada um poderá, pelas suas páginas, com a responsabilidade de sua assinatura, manifestar as suas preferências, comunicar as suas intuições, dizer os seus julgamentos, quaisquer que sejam" (BARRETO, 1907, p. 4-5).

$\mathrm{Na}$ concepção do editor, Floreal trazia primordialmente "nomes dispostos a dizer abnegadamente as suas opiniões sobre tudo o que interessar a nossa sociedade, guardando as conveniências de quem quer ser respeitado" (BARRETO, 1907, p. 4). Esse caráter tão afirmadamente autoral que Lima Barreto imprime à Floreal é como um grito de afirmação de um indivíduo que sonha e deseja pra si um destino literário. Um grito e um desabafo de quem quer escrever e não encontra espaço. Está lá no mesmo editorial da Floreal, o desabafo a que me refiro. Usando a primeira pessoa do plural, já que em nenhum momento deixa de reconhecer a revista como uma empreitada coletiva, que partilha com nomes como Antonio Noronha Santos - amigo de toda uma vida -, Domingos Ribeiro Filho e Mário Tibúrcio Gomes Carneiro, declara: 
Há entre nós uma razão de completo contato: é a nossa incapacidade de tentar os meios de publicidade habituais e o nosso dever de nos publicar.

Este caminho se nos impunha, pois nenhum de nós teve a rara felicidade de nascer de pai livreiro, e pouca gente sabe que, não sendo assim, só há um meio de se chegar ao editor - é o jornal. (BARRETO, 1907, p. 5).

Tal como Veiga Filho, em Recordações do escrivão Isaías Caminha, fabricara a sua própria notoriedade, Nabor - no conto "O jornalista" - se dispõe a fabricar os fatos que deseja noticiar no seu jornal. O problema é que em Sant'Ana "não havia incêndios, nem mesmo casuais" (BARRETO, 2010, p. 531). Então era preciso um incêndio. Inicialmente o personagem cogita pagar alguém para atear fogo num palacete da cidade. Pensando bem, avalia que assim poderia vir a ser descoberto e denunciado. Eis que lhe surge uma ideia para levar adiante seus planos: "Ele mesmo poria fogo no sábado, na véspera de sair o seu hebdomadário - O Arauto. Antes escreveria uma longa notícia com todos os 'ff' e 'rr'. Dito e feito. $O$ palácio pegou fogo inteirinho no sábado, alta noite; e de manhã, a notícia saía bem feitinha". (BARRETO, 2010, p. 531).

O insólito procedimento de provocar um incêndio para se produzir a notícia sobre o mesmo pode até parecer absurdo, mas não é. É evidente que nada pode sustentar um possível parentesco atávico entre jornalistas e incendiários, mas é indiscutível a apreciação crítica que Lima Barreto produz sobre os métodos de fazer jornalismo na Primeira República - e, quiçá, aplica-se a um período de tempo que chega até o presente. Está claro que o autor quer dizer algo sobre a imprensa do seu tempo, que ele conheceu tão bem e na qual atuou intensamente. Sobretudo se considerarmos o desfecho do conto, tal como reproduzido a seguir:

Fagundes, que era juiz municipal, logo viu a criminalidade de Nabor. Arranjou-lhe uma denúncia processo e o grande jornalista Salomão Nabor de Azevedo, descendente dos Azevedos, do Rio Claro, e dos Breves, reis da escravatura, foi parar na cadeia, pela sua estupidez e vaidade. (BARRETO, 2010, p. 531).

Desonestidade criminosa, estupidez e vaidade são as características atribuídas a um "grande jornalista". Estes são os atributos que qualificam um homem de imprensa, segundo a ficção de Lima Barreto, que pretende denunciar também a origem nobre e senhorial de Nabor. Trata-se, afinal, de um "descendente dos reis da escravatura", cujo pretenso abolicionismo já fora desmascarado em trecho anterior do conto. Portanto, na pena do "mulato de Todos os Santos", Nabor parece merecedor do cárcere não só pela venalidade do jornalismo que pratica, mas também pelo passado que o condena, pela herança escravocrata. 
A trajetória de Lima Barreto e a de muitos de seus personagens merecem ser analisadas como experiências sobre as quais o historiador deve se debruçar, tomando por base o que Thompson preceitua:

\begin{abstract}
As pessoas não experimentam sua própria experiência apenas como idéias, no âmbito do pensamento e de seus procedimentos, ou (como supõem alguns praticantes teóricos) como instinto proletário etc. Elas também experimentam sua experiência como sentimento e lidam com esses sentimentos na cultura, como normas, obrigações familiares e de parentesco, e reciprocidades, como valores ou (através de formas mais elaboradas) na arte ou nas convicções religiosas. Essa metade da cultura (e é uma metade completa) pode ser descrita como consciência afetiva e moral (THOMPSON, 1981, p. 189).
\end{abstract}

Certamente o autor aqui em questão lida com sua experiência através da produção literária, sua arte. Trata-se do modo como se constitui em agente da história e dela participa, nela intervindo. Seu engajamento e militância deram-se, sobretudo, na arena da cultura, denunciando os mecanismos de uma imprensa e de um jornalismo que ainda hoje insiste em invocar para si neutralidade, imparcialidade e isenção, ocultando seus interesses políticos, ideológicos e de classe. E bem sabemos que essa imprensa, ao longo do tempo, tem sido capaz de tudo, ou quase tudo. Se não chega a provocar incêndios para transformá-los em notícia, não hesita ante a possibilidade de incinerar a reputação de todos aqueles cujos interesses lhe são contrários. E o que são esses interesses senão interesses de classe?

A breve análise de um conto, desenvolvida nesse artigo, sugere ainda uma reflexão sobre um questionamento persistente: como fazer história a partir da ficção? É isto mesmo cabível, sobretudo quando se postula uma oposição ao relativismo pós-moderno, que insiste em considerar a história apenas mais um gênero narrativo?

Entendemos que a história é uma forma de conhecimento do passado. E por se tratar de um conhecimento, é algo construído pelo historiador através da pesquisa de fontes. Afinal, o passado é inacessível e nossa relação com ele é assim mediada pelas fontes. Isso não significa dizer que o passado não existiu e que tudo é, portanto, construção. O que apenas se admite aqui é o imprescindível papel de mediação das fontes no ofício do historiador. Não questionamos a existência da verdade, mas apenas reconhecemos que o máximo que podemos alcançar é a verossimilhança. Tecemos, portanto, versões sobre o passado, que são informadas por elementos de natureza variada, notadamente aquelas de caráter político e ideológico.

Por isso a história caracteriza-se por um embate constante e dinâmico entre diferentes versões. Embate esse atravessado por interesses também políticos, ideológicos, econômicos e de classe - na perspectiva relacional thompsoniana. Desta forma, cabe ao historiador 
submeter suas fontes ao habitual interrogatório minucioso que é capaz de revelar também as construções que qualquer "documento" nos apresenta sobre o passado.

O que fazer então diante da ficção? A literatura é aqui tomada como um documento ou uma fonte como outra qualquer. Sobre ela recai, portanto, o repertório habitual de questões formuladas a partir do campo da história social: quem escreve? Em que condições sociais, políticas, econômicas e culturais o faz? Como o produto do seu trabalho é apropriado, lido e "consumido"? Dito de outro modo, pensar a literatura como fonte documental é pensar, simultaneamente, sobre o escritor como intelectual, sobre as condições de produção da materialidade da obra, sobre o público leitor e suas estratégias e apropriações de leitura.

A literatura requer também do historiador a compreensão da complexa relação entre texto e contexto. Tal como propôs Antonio Candido, o texto não é somente resultado do gênio criador. É também, indiscutivelmente, criação do autor, mas reflete em certo grau as determinações do contexto histórico no qual foi produzido, com suas respectivas injunções políticas, sociais, econômicas e culturais. O que temos é uma relação dialética entre texto e contexto, que necessariamente precisa ser observada (CANDIDO, 2006).

Sant'Ana dos Pescadores, Salomão Nabor de Azevedo, Fagundes, Veiga Filho, O Arauto e $O$ Globo são frutos da criação literária de Lima Barreto. Mas esta criação foi seguramente determinada pelos aspectos históricos da Primeira República e pelos modos de fazer jornalismo usualmente empregados naquele período. A ficção aqui é um documento tão ou mais eloquente sobre as intervenções do literato naquele tempo, quanto qualquer texto não ficcional.

Sabemos também, como sugere Thompson, que sempre se fazem escolhas. E o historiador precisa estar atento para desvendá-las. No início da década de 1920, Lima Barreto já adquirira plena conviç̧ão de que o jornal não é o lugar onde a informação pode ser veiculada de forma imparcial e isenta. É antes, um campo de lutas e embates entre diferentes versões sobre a realidade, versões inegavelmente comprometidas com alguma perspectiva ideológica. Vejamos o seguinte trecho de uma crônica:

O que é preciso, portanto, é que cada qual respeite a opinião de qualquer, para que desse choque surja o esclarecimento do nosso destino, para própria felicidade da espécie humana.

Entretanto, no Brasil, não se quer isto. Procura-se abafar as opiniões, para só deixar em campo os desejos dos poderosos e prepotentes. Os órgãos de publicidade por onde se podiam elas revelar são fechados e não aceitam nada que os possa lesar.

Dessa forma, quem, como eu, nasceu pobre e não quer ceder uma linha da sua independência de espírito e inteligência, só tem que fazer elogios à Morte. 
[...] Sendo assim, eu a sagro, antes que ela me sagre na minha pobreza, na minha infelicidade, na minha desgraça e na minha honestidade. Ao vencedor, as batatas!(BARRETO, 2004, p. 391).

Talvez seja importante ressaltar que a leitura que fazemos de jornais, revistas, artigos, crônicas e obras literárias estão inseridas no campo da história, tal como Sidney Chalhoub o descreve em seu mais recente livro, intitulado $A$ força da escravidão, ao revisitar a obra de Machado de Assis. São leituras "fincadas na terra e no estrume da história à qual não se pode escapar" (CHALHOUB, 2012, p. 31).

E são leituras que nos permitem perceber que importância de analisar "o significado desse jornalismo marginal na história da cultura brasileira e delimitar sua extensão, sua força e sua influência intelectual e moral sobre o conjunto da sociedade" (COUTINHO, 2008, p. 66), enriquecendo assim a historiografia que ousa frequentar essas encruzilhadas em que a imprensa e a literatura se encontraram.

\section{Referências}

BARBOSA, Francisco de Assis. A vida de Lima Barreto. 7. ed. Belo Horizonte: São Paulo: Universidade de São Paulo, 1988.

BARRETO, Lima. Recordações do escrivão Isaías Caminha. In: Lima Barreto: prosa seleta. Rio de Janeiro: Nova Aguilar, 2001a. p. 113-257.

. Numa e a Ninfa. In: Lima Barreto: prosa seleta. Rio de Janeiro: Nova Aguilar, 2001b. p. 413-554.

_ _ _ _ _. Cemitério dos vivos. São Paulo: Brasiliense, 1956a.

_ _ _ _ . Feiras e Mafuás. São Paulo: Brasiliense, 1956b.

- _ - _ . Clara dos Anjos. São Paulo: Brasiliense, 1956c.

_ _ _ _ _. Correspondência ativa e passiva. São Paulo: Brasiliense, 1956d. t. 2.

_ - _ _ _ . Impressões de leitura. São Paulo: Brasiliense, 1956e.

_ _ _. O jornalista. Souza Cruz, Rio de Janeiro, ano 6, n. 55, jul. 1921a.

As origens. Souza Cruz, Rio de Janeiro, ano 6, n. 49, jan. $1921 \mathrm{~b}$.

. O destino da literatura. Souza Cruz, Rio de Janeiro, Ano 6, n. 58/59, out./nov. 1921c. 
. O jornalista. In: SCHWARCZ, Lilia Moritz (Org.). Contos completos de Lima Barreto. São Paulo: Companhia das Letras, 2010. p. 527-531.

Artigo inicial. Floreal, Rio de Janeiro, Ano 1, n. 1, p. 3-7, out. 1907.

_. Elogio da morte. In: RESENDE, Beatriz; VALENÇA, Rachel (Org.). Toda crônica: Lima Barreto. Rio de Janeiro: Agir, 2004. v. 1, p. 390-391.

BOTELHO, Denilson. A pátria que quisera ter era um mito: o Rio de Janeiro e a militância literária de Lima Barreto. Rio de Janeiro: Secretaria Municipal das Culturas, Departamento Geral de Documentação e Informação Cultural, Divisão de Editoração, 2002. (Coleção Biblioteca Carioca, 44).

. Sob o signo da Floreal; uma perspectiva histórica da iniciação literária de Lima Barreto. Itinerários, Araraquara, v. 23, p. 149-174, 2005.

Lima Barreto e o engenhoso aparelho de aparições e eclipses: reflexões sobre a história da imprensa. In: SIMPÓSIO NACIONAL DA ASSOCIAÇÃO NACIONAL DE HISTÓRIA, 26., 2011, São Paulo. Anais... São Paulo: ANPUH-SP, 2011. Disponível em: <http://www.snh2011.anpuh.org/resources/anais/14/1300224155_ARQUIVO_ComunicacaoA npuh2011DenilsonBotelho.pdf >. Acesso em: 29 mar. 2013.

BOTELHO, Denílson; AZEVEDO NETO, Joachin de Melo. E a literatura, serve para quê? Tensões e convergências entre José Veríssimo e Lima Barreto. Revista Estudos Amazônicos, Guamá, v. $7, \quad$ n. $1, \quad$ p. 150-173, 2012. Disponível em: <http://www3.ufpa.br/ifch/Botelho_Azevedo_6.pdf>. Acesso em: 31 maio 2013.

CAMARGO, Maria Lúcia. Revistas literárias contemporâneas. In: LUSTOSA, Isabel (Org.). Imprensa, história e literatura. Rio de Janeiro: Edições Casa de Rui Barbosa, 2008. p. 255-277.

CANDIDO, Antonio. Literatura e sociedade. Rio de Janeiro: Ouro sobre Azul, 2006.

CARVALHO, Maria Alice Rezende de. Irineu Marinho: imprensa e cidade. São Paulo: Globo, 2012.

CARVALHO NETO, Paulo de. Um lugar para Ranulfo Prata. Revista Interamericana de Bibliografia: Órgano de Estudios Humanísticos (Inter-American Review of Bibliography. Journal of Humanistic Studies), Washington, v. 26, n. 1, p. 3-30, Ene./Mar. 1974. Disponível em: <http://143.107.31.231/Acervo_Imagens/Revista/REV012/Media/REV12-11.pdf >. Acesso em: 31 maio 2013.

CEVASCO, Maria Elisa. Dez lições sobre estudos culturais. São Paulo: Boitempo, 2003. 
CHALHOUB, Sidney. A força da escravidão: ilegalidade e costume no Brasil oitocentista. São Paulo: Companhia das Letras, 2012.

COUTINHO, Eduardo Granja. Processos contra-hegemônicos na imprensa carioca, 1889-1930. Comunicação e contra-hegemonia: processos culturais e comunicacionais de contestação, pressão e resistência. Rio de Janeiro, Editora da UFRJ, 2008. p. 65-89.

FERREIRA, Marieta de Morais. "MOSES, Herbert" in Dicionário Histórico-Biográfico Brasileiro pós-1930. 2. ed. Rio de Janeiro: FGV, 2001. v. 4, p. 3922-3923.

OAKLEY, Robert John. Lima Barreto e o destino da literatura. São Paulo: Unesp, 2011.

RESENDE, Beatriz; VALENÇA, Rachel (Org.). Toda crônica: Lima Barreto. Rio de Janeiro: Agir, 2004. $2 \mathrm{v}$.

SCHWARCZ, Lilia Moritz (Org.). Contos completos de Lima Barreto. São Paulo: Companhia das Letras, 2010.

SEVCENKO, Nicolau. Literatura como missão: tensões sociais e criação cultural na Primeira República. 2. ed. São Paulo: Companhia das Letras, 2003.

SODRÉ, Nelson Werneck. A história da imprensa no Brasil. Rio de Janeiro: Civilização Brasileira, 1966.

THOMPSON, Edward. Palmer. A miséria da teoria ou um planetário de erros: uma crítica ao pensamento de Althusser. Rio de Janeiro: Zahar, 1981.

WOOD, Ellen Meiksins. O que é a agenda 'pós-moderna'? In: WOOD, Ellen; FOSTER, John Bellamy (Org.). Em defesa da história: marxismo e pós-modernismo. Rio de Janeiro: Jorge Zahar, 1999. p. 7-22. 